\title{
MENGEMBANGKAN PEMBELAJARAN DAN PENILAIAN BERPIKIR TINGKAT TINGGI PADA MATA PELAJARAN SEJARAH SMA
}

\author{
Pi'i \\ SMA Negeri 1 Turen Kabupaten Malang
}

\begin{abstract}
Abstrak. Salah satu permasalahan pembelajaran sejarah adalah ketiadaan keberanian dalam mengembangkan pembelajaran dan penilaian berpikir tingkat tinggi. Hal ini berdampak dari pembelajaran sejarah yang dilaksanakan secara konvensional. Guru menjadi titik sentral (teacher centered) dalam pembelajaran dengan gaya bertutur, bercerita atau ceramah, dan penilaian hasil belajar yang hanya menuntut perilaku "ingatan" yang cenderung teroritis dan tidak bersifat kontekstual. Untuk memecahkan permasalahan tersebut, guru sejarah merupakan salah satu komponen penting yang langsung berhadapan dengan peserta didik dalam proses pembelajaran. Maka, sebagai guru sejarah dalam melaksanakan pembelajaran sebaiknya mengacu pada paradigma baru dalam pembelajaran kontruktivisme yang berorientasi dari pembelajaran yang berpusat pada guru (teacher centered) beralih ke peserta didik (student centered) sehingga mampu memberikan ruang gerak kepada peserta untuk meningkatkan kemampuan menalar, berpikir kritis, logis, dan menumbuhkan kreativitas berpikir peserta didik. Guru sejarah juga sebaiknya mampu melaksanakan penilaian berpikir tingkat tinggi sesuai dengan tuntutan Kompetensi Dasar (KD) yang level kognitifnya berpikir tingkat tinggi.
\end{abstract}

Kata-kata kunci: level kognitif, pembelajaran, berpikir tingkat tinggi

Abstract. An existing problem of history teaching is teachers' afraid in developing teaching and higher order thinking evaluation. The conventional teaching of history and teacher centred learning with textual teaching process causes the problem. History teachers should change their mind-set to solve the related problem. Therefore, teachers should teach based on the new paradigm, so-called constructivism. The newer paradigm could create a space for students to reason, think critically, and think creatively. History teachers are able to teach the higher order thinking based on its basic competence.

Keywords: cognitive level, teaching, higher order thinking

Permasalahan pembelajaran sejarah merupakan permasalahan yang selalu aktual menjadi bahan kajian khususnya para dosen sejarah maupun guru sejarah dalam kegiatan MGMP (Musyawarah Guru Mata Pelajaran), serta mencari solusi untuk menyempurnakan proses pembelajaran. Permasalahan tersebut antara lain adalah kurangnya keterampilan guru sejarah dalam mengembangkan berfikir tingkat tinggi baik berkaitan dengan proses pembelajaran maupun penilaian hasil belajar. Pembelajaran berfungsi untuk mengantarkan peserta didik untuk mencapai kemampuan yang dituntut dalam KD (Kompetensi Dasar), sedangkan penilaian hasil belajar sebagai alat untuk mengukur keberhasilan proses pembelajaran dan ketercapaian kemampuan peserta didik terhadap tuntutan KD.
Hal ini berarti KD menjadi acuan dalam proses pembelajaran maupun penilaian hasil belajar peserta didik. Artinya, pelaksanaan pembelajaran dan penilaian hasil belajar menyesuaikan dengan tuntutan level kognitif KD. Jika, kemampuan yang dituntut oleh KD pada level berfikir tingkat tinggi, maka pelaksanaan pembelajaran dan penilaian hasil belajar sebaiknya dilaksanakan pada level yang sama..

Kenyataannya di lapangan, sebagian besar guru sejarah cenderung mengabaikan tuntutan KD, tetapi lebih mengacu pada buku pelajaran (paket), meski buku pelajaran tersebut kurang sesuai dengan tuntutan KD. Hal ini merupakan dampak dari keengganan guru sejarah beranjak dari sistem pembelajaran konvensional "zona nyaman" yang mengedepankan gaya 
bertutur, bercerita atau ceramah. Pola pembelajaran yang menjadikan dirinya sebagai titik sentral (teacher centered) dalam pembelajaran ini, pada dasarnya kurang memberikan ruang gerak kepada peserta didik dalam mengembangkan berfikir kritis dan logis, bahkan pola pembelajaran konvensional ini cenderung membelenggu kreatifitas berfikir peserta didik.

Demikian pula dalam melaksanakan penilaian hasil belajar, sebagian besar guru sejarah masih cenderung melaksanakan penilaian pada level kognitif berfikir tingkat rendah (Low Order Thinkhing Skill/LOTS) dengan butir soal yang menuntut perilaku "ingatan". Penulisan butir soal yang mengukur perilaku "ingatan" diyakini lebih mudah antara lain yaitu mudah dalam penulisan soalnya, dan materi yang ditanyakan diperoleh dari buku pelajaran (Safari, 2004; 15). Bila dilihat dari konteksnya penilaian berfikir tingkat rendah (Low Order Thinkhing Skill/LOTS) sebagian besar menggunakan konteks di dalam kelas dan sangat teoritis, serta jarang menggunakan konteks di luar kelas sehingga tidak memperlihatkaan keterkaitan antara pengetahuan yang diperoleh di kelas dengan situasi nyata dalam kehidupan sehari-hari (Widana, 2016; 2)..

Sebaliknya, guru sejarah merasa enggan menulis butir soal yang mengukur perilaku pada level berfikir tingkat tinggi (Higher Order Thinkhing Skill/HOTS) yang mencakup kemampuan menganalisis, mengevaluasi dan mengkreasi. Hal ini disebabkan beberapa kesulitan antara lain yaitu; (1) menentukan perilaku yang akan diukur, (2) merumuskan masalah yang akan dijadikan sebagai dasar pertanyaan (stimulus), (3) materi yang ditanyakan tidak selalu tersedia dalam buku pelajaran, dan menuntut penalaran tingkat tinggi. Akibatnya peserta didik selalu dikondisikan dengan pola "ingatan" seperti pembelajaran, mengerjakan PR, tugas-tugas yang selalu berpola "ingatan" (Safari, 2004; 15), meskipun KD yang akan dicapai pada level berfikir tingkat tinggi.

Penerapan pembelajaran konvensional dan penilaian yang hanya mengacu pada penilaian level berfikir tingkat rendah seperti mengukur perilaku "ingatan", berdampak kemampuan literasi peserta didik Indonesia di kancah internasional masih sangat rendah. Hal ini dibuktikan dari hasil studi internasional PISA (Programme for International Student Assessment) yang meliputi kegiatan literasi membaca (reading literacy), literasi matematika (mathematical literacy), dan literasi sains (scientific literacy) bahwa peserta didik Indonesia prestasinya sangat rendah dalam (1) memahami informasi yang kompleks; (2) teori, analisis, dan pemecahan masalah; (3) pemakaian alat, prosedur dan pemecahan masalah; dan (4) melakukan investigasi (Widana, 2016; 2).

Oleh karena itu, perlu dikembangkan sistem pembelajaran yang memberikan ruang gerak kepada peserta didik untuk meningkatkan kemampuan berfikir kritis, logis dan kreatif sehingga mampu mengantarkan peserta didik mencapai kemampuan yang dituntut oleh KD yang level kognitifnya berfikir tingkat tinggi. Serta mampu melaksanakan sistem penilaian berfikir tingkat tinggi (Higher Order Thinkhing Skill/HOTS), suatu penilaian yang menuntut kemampuan penalaran tingkat tinggi, kreatifitas berfikir, dan membangun kemandirian peserta didik dalam memecahkan masalah. Sehubungan dengan hal tersebut, Kemendikbud telah menyisipkan sekitar 20\% soal HOTS (Higher Order Thinkhing Skill) dalam Ujian Nasional (UN) pada tahun pelajaran 2015-2016. Bahkan untuk menghadapi Ujian Sekolah (US) SMA tahun pelajaran 2016-2017 Kemendikbud telah menyusun modul penulisan soal HOTS. Hal ini menunjukkan bahwa setiap guru, termasuk guru sejarah wajib melaksanakan penilaian hasil belajar dengan menggunakan soal-soal HOTS untuk memenuhi tuntutan $\mathrm{KD}$ yang level kognitifnya berfikir tingkat tinggi.

\section{LEVEL KOGNITIF KD SEJARAH}

Anderson \& Krathwohl mengklasifikasikan dimensi proses berfikir menjadi tiga level kognitif yaitu; (1) kemampuan berfikir tingkat rendah (Low Order Thinkhing Skill/LOTS) meliputi dimensi proses berfikir; mengetahui (mengingat), (2) kemampuan berfikir tingkat menengah (Middle Order Thinking Skill/MOTS) meliputi dimensi proses berfikir; 
memahami dan mengaplikasi, dan (3) kemampuan berfikir tingkat tinggi (Higher Order Thinkhing Skill/HOTS) meliputi dimensi proses berfikir; menganalisis, mengevaluasi dan mengkreasi. Untuk lebih jelasnya mengenai level kognitif dan dimensi proses berfikir marilah kita lihat tabel berikut ini.

\begin{tabular}{|c|c|c|}
\hline \multirow{3}{*}{ HOTS } & Mengkreasi & $\begin{array}{l}\text { - Mengkreasi ide/gagasan sendiri. } \\
\text { - Kata kerja: mengkonstruksi, desain, kreasi, mengembangkan, } \\
\text { menulis, memformulasikan. }\end{array}$ \\
\hline & Mengevaluasi & $\begin{array}{l}\text { - Mengambil keputusan sendiri. } \\
\text { - Kata kerja: evaluasi, menilai, menyanggah, memutuskan, } \\
\text { memilih, mendukung. }\end{array}$ \\
\hline & Menganalisis & $\begin{array}{l}\text { Menspesifikasi aspek-aspek/elemen. } \\
\text { Kata kerja: membandingkan, memeriksa, , mengkritisi, } \\
\text { menguji. }\end{array}$ \\
\hline \multirow{2}{*}{ MOTS } & Mengaplikasi & $\begin{array}{l}\text { Menggunakan informasi pada domain berbeda } \\
\text { Kata kerja: menggunakan, mendemonstrasikan, } \\
\text { mengilustrasikan, mengoperasikan. }\end{array}$ \\
\hline & Memahami & $\begin{array}{l}\text { - Menjelaskan ide/konsep. } \\
\text { Kata kerja: menjelaskan, mengklasifikasi, menerima, } \\
\text { melaporkan. }\end{array}$ \\
\hline LOTS & Mengetahui & $\begin{array}{l}\text { - Mengingat kembali. } \\
\text { - Kata kerja: mengingat, mendaftar, mengulang, menirukan. }\end{array}$ \\
\hline
\end{tabular}

Sumber: Anderson \& Krathwohl dalam Widana (2016; 12)

Level kognitif dan dimensi proses berfikir tercermin dalam KD pengetahuan semua mapel termasuk mapel Sejarah (wajib dan peminatan IPS). KD merupakan kemampuan spesifik yang mencakup sikap, pengetahuan, dan keterampilan yang terkait muatan atau mapel (Lampiran Permendikbud Nomor 22 Tahun 2016). Aspek pengetahuan berkaitan dengan pengembangan materi/bahan pembelajaran, dan aspek keterampilan berkaitan keterampilam dan pengalaman belajar peserta didik (Direktorat Pembinaan SMA, 2014; 1). Sedangkan aspek sikap (spiritual dan sosial) dicapai melalui pembelajaran tidak langsung (indirect teaching), yaitu keteladanan, pembiasaan, dan budaya sekolah dengan memperhatikan karakteristik mata pelajaran, serta kebutuhan dan kondisi siswa (Permendikbud Nomor 24 Tahun 2016).

KD dari KI-3 (pengetahuan) dan KD dari KI-4 (keterampilan) mapel Sejarah Indonesia (wajib) sebagaimana yang terdapat dalam Permendikbud Nomor 24 Tahun 2016 masingmasing terdapat $27 \mathrm{KD}$ yang terdiri atas; $8 \mathrm{KD}$ untuk kelas X, $10 \mathrm{KD}$ untuk kelas XI, dan $9 \mathrm{KD}$ untuk kelas XII. Dari 8 KD pengetahuan untuk kelas $\mathrm{X}$, terdapat $3 \mathrm{KD}(3.1,3.2$ dan 3.4) pada level kemampuan berfikir tingkat rendah pada dimensi proses berfikir "memahami", dan $5 \mathrm{KD}$ (3.3, 3.5, 3.6, 3.7 dan 3.8) pada level berfikir tingkat tinggi pada dimensi proses berfikir "menganalisis". KD pengetahuan untuk kelas XI semuanya pada kemampuan berfikir tingkat tinggi yang terdiri atas $10 \mathrm{KD}(3.1,3.2,3.3,3.5$, 3.6, 3.7, 3.8, 3.9, dan 3.10) pada dimensi proses berfikir "menganalisis", dan $1 \mathrm{KD}$ (3.4) dimensi proses berfikir mengevaluasi (menghargai nilainilai). Demikian pula untuk kelas XII terdapat 9 KD seluruhnya juga berada pada kemampuan berfikir tingkat tinggi yang terdiri atas $5 \mathrm{KD}$ (3.1, 3.3, 3.4, 3.5, 3.6) pada dimensi proses berfikir "menganalisis", dan $4 \mathrm{KD}(3.2,3.7,3.8$ dan 3.9) pada dimensi proses berfikir "mengevaluasi".

Sedangkan keterampilan (KI-4) yang akan dicapai pada kelas X, XI dan XII yaitu "mengolah, menalar, dan menyaji dalam ranah konkret dan ranah abstrak ...". Untuk kelas X terdapat 8 KD dari KI-4 yang meliputi keterampilan yaitu; (1) mengolah informasi (KD 4.5 dan 4.7), (2) menerapkan (KD 4.2), dan (3) menyajikan (KD 4.1, 4.3, 4.4, 4.6, dan 4.8). Kelas XI keterampilan yang ingin dicapai meliputi yaitu; (1) mengolah informasi (KD 4.1, 4.2, 
4.10), (2) menalar (KD 4.3, 4.5, 4.7, dan 4.8), (3) menyajikan (KD 4.4), dan (4) menulis /menuliskan (KD 4.6 dan 4.9). Sedangkan kelas XII terdapat $10 \mathrm{KD}$ keterampilan yang dicapai peserta didik meliputi yaitu; (1) melakukan penelitian (KD 4.4, 4.5, dan 4.6), (2) "merekontruksi" (KD 4.1 dan 4.3), (3) "menulis/menuliskan" (KD 4.2 dan 4.7), (4) "menyajikan" (KD 4.8), dan (5) "membuat studi evaluasi" (KD 4.9).

Sedangkan KD dari KI-3 (pengetahuan) dan KD dari KI-4 (keterampilan) mapel Sejarah (Peminatan IPS) kelas X masing-masing terdapat $11 \mathrm{KD}$, kelas XI masing-masing $12 \mathrm{KD}$, dan kelas XII masing-masing $6 \mathrm{KD}$. Kelas X terdapat 11 $\mathrm{KD}$ pengetahuan yang terdiri atas $1 \mathrm{KD}$ (3.7) pada level berfikir tingkat rendah pada dimensi proses berfikir "memahami", dan $10 \mathrm{KD}(3.1,3.2,3.3$, $3.4,3.5,3.8,3.9,3.10,3.11$ dan 3.12) berada pada level berfikir tingkat tinggi pada dimensi proses berfikir "menganalisis". Kelas XI terdapat $12 \mathrm{KD}$ yang seluruhnya pada level berfikir tingkat tinggi pada dimensi proses berfikir "menganalisis". KD untuk kelas XII seluruhnya juga berada pada kemampuan berfikir tingkat tinggi yang terdiri atas yaitu $4 \mathrm{KD} \quad(3.1,3.3,3.4$ dan 3.6) pada dimensi proses berfikir "menganalisis", dan $2 \mathrm{KD}$ (3.2 dan 3.5) pada dimensi proses berfikir "mengevaluasi".

Sementara itu, aspek keterampilan (KI-4) dari mapel sejarah kelas X dan XI diharapkan peserta didik memiliki keterampilan "mengolah, menalar, dan menyaji dalam ranah konkret dan ranah abstrak ..." Kelas X terdapat 11 KD dari KI-4 (keterampilan) yang terdiri atas yaitu; (1) keterampilan "menerapkan" (KD. 4.7), (2) keterampilan "menyajikan" (KD. 4.1, 4.2, 4.4, 4.5, 4.6, 4.8, 4.9, 4.11), (3) keterampilan "membuat tulisan", dan (4) keterampilan "menarik kesimpulan". Sedangkan kelas XI terdapat $12 \mathrm{KD}$ dari KI-4 (keterampilan) yang meliputi (1) keterampilan "mengolah informasi", (2) keterampilan "menyajikan" (3) keterampilan "menyusun cerita sejarah", dan (4) keterampilan "membuat karya tulis" Aspek keterampilan (KI4) pada kelas XII diharapkan peserta didik memiliki keterampilan "mengolah, menalar, menyaji" dan mengkreasi. Hal ini menunjukkan adanya peningkatan kompetensi dibandingkan dengan kelas XI yaitu keterampilan mengkreasi/mencipta. Kelas XII terdapat $6 \mathrm{KD}$ dari KI-4 (keterampilan) yang terdiri atas; (1) keterampilan "menyajikan" dan (2) keterampilan "merekonstruksi".

KD dari KI-3 (pengetahuan) mapel Sejarah Indonesia (wajib) secara total $27 \mathrm{KD}$ yang terdiri atas $3 \mathrm{KD}$ pada level berfikir tingkat rendah pada dimensi proses berfikir "memahami" (kelas X), dan $24 \mathrm{KD}$ selebihnya berada pada level berfikir tingkat tinggi. Hal ini mengidikasikan meskipun mapel Sejarah Indonesia (wajib) diorientasikan untuk membentuk sikap dan karakter bangsa, tetapi tidak mengesampingkan sejarah sebagai ilmu. Sedangkan KD dari KI-3 (pengetahuan) pada mapel Sejarah (peminatan IPS) SMA secara total sebanyak $29 \mathrm{KD}$ yang terdiri atas $1 \mathrm{KD}$ pada level berfikir tingkat rendah pada dimensi proses berfikir "memahami", dan $28 \mathrm{KD}$ selebihnya pada level berfikir tingkat tinggi pada dimensi proses berfikir "menganalisis dan mengevaluasi". Mapel Sejarah (peminatan IPS) diharapkan peserta didik mampu berfikir sejarah (historical thinking) dan memiliki keterampilan sejarah (historical skill). Jadi penekanannya lebih pada sejarah sebagai ranah ilmu (Zuhdi, 2014: 2).

Sedangkan aspek keterampilan yang dikembangkan dalam mapel Sejarah Indonesia (wajib) dan mapel Sejarah (peminatan IPS) tidak hanya menyangkut keterampilan konkrit tetapi juga keterampilan abstrak. Keterampilan konkrit merupakan tindak motorik yang hasilnya cenderung berupa karya benda misalnya membuat laporan tertulis hasil penelitian sederhana. Sedangkan keterampilan abstrak merupakan kemampuan pikir dan tindak mental non motorik seperti menalar dan mengambil keputusan. Keterampilan abstrak mencakup kemampuan belajar dan kemampuan berfikir. Kemampuan belajar meliputi mengamati, menanya, mengumpulkan informasi, menalar/mengasosiasi, dan mengkomunikasikan. Sedangkan kemampuan berfikir meliputi mengingat, memahami, menerapkan, menganalisis, mengevaluasi dan mencipta (Direktorat Pembinaan SMA, 2014; 10). Hal ini menunjukkan bahwa aspek keterampilan 
khususnya keterampilan abstrak juga merujuk pada level kognitif. Dengan demikian aspek keterampilan yang diperoleh peserta didik pada mapel Sejarah Indonesia (wajib) dan mapel Sejarah (peminatan IPS) sebagaimana yang dipaparkan di atas seperti menalar, merekontruksi, menyajikan, menarik kesimpulan, membuat tulisan/cerita sejarah, membuat karya tulis, dapat dikategorikan ke dalam level berfikir tingkat tinggi.

\section{KD, PEMBELAJARAN, DAN PENILAIAN}

KD merupakan kemampuan yang diperoleh peserta didik melalui proses pembelajaran. Untuk mempermudah pencapaian kemampuan yang dituntut oleh $\mathrm{KD}$, maka $\mathrm{KD}$ dijabarkan ke dalam sejumlah Indikator Pencapaian Kompetensi (IPK). IPK merupakan penanda suatu kompetensi yang dipelajari telah dikuasai. IPK sikap merupakan perilaku yang dapat diamati, sedangkan IPK pengetahuan dan keterampilan merupakan perilaku yang dapat diamati dan diukur (Permendikbud Nomor 103 Tahun 2014). IPK pengetahuan dan keterampilan dirumuskan dengan menggunakan kata kerja operasional, bergradasi dan sistematis hingga tingkat paling tinggi. IPK pengetahuan berkaitan erat dengan dimensi pengetahuan (faktual, konseptual, prosedural dan metakognitif) dan dimensi proses kognitif (mengingat, memahami, menerapkan, menganalisis, mengevaluasi dan mencipta/mengkreasi). Sedangkan, IPK keterampilan berkaitan dengan ranah abstrak dan konkrit (Direktorat Pembinaan SMA, 2014; 4).

Bobot antara KD dengan sejumlah IPK yang merupakan penjabaran dari KD harus sama atau seimbang. Sehingga, pencapaian kemampuan terhadap sejumlah IPK yang merupakan penjabaran dari KD tersebut, berarti telah mencapai kompetensi yang diharapkan dalam KD. Hal ini mengidikasikan bahwa IPK menjadi tolok ukur pencapaian KD. Bobot KD berpengaruh terhadap jumlah pertemuan. KD semakin berbobot semakin banyak diperlukan jumlah pertemuan dalam pembelajaran. Demikian pula level kognitif yang tercermin dalam KD berpengaruh pula terhadap pelaksanaan pembelajaran utamanya dalam menentukan metode yang tepat yang diyakini mampu mengantarkan peserta didik dalam mencapai kompetensi yang terdapat dalam KD.

$\mathrm{KD}$ dari KI-3 (pengetahuan) level kognitifnya berfikir tingkat tinggi sebaiknya pelaksanaan pembelajaran menyelaraskan dengan tuntutan KD itu. Artinya, jika tuntutan KD-nya pada level berfikir tingkat tinggi, maka pelaksanaan pembelajarannya juga berada pada level yang sama. Pembelajaran berfikir tingkat tinggi merupakan pembelajaran yang menerapkan model pembelajaran tertentu yang mampu mengantarkan peserta didik mampu mencapai tuntutan KD yang berada pada level berfikir tingkat tinggi. Model pembelajaran yang lebih tepat untuk mengantarkan peserta didik mencapai tuntutan KD pada level berfikir tingkat tinggi antara lain dengan menggunakan model cooperative learning. Pembelajaran cooperative merupakan sistem pembelajaran yang berbasis faham kontruktivisme (PPPP BP SDM, 2014: 36) yang mengubah orientasi pembelajaran dari berpusat pada guru (teacher centered) beralih ke peserta didik (student centered). Model cooperative learning merupakan sistem pembelajaran yang memberikan kesempatan kepada peserta didik untuk bekerja sama dengan sesama peserta didik dalam menyelesaikan tugastugas yang terstruktur (Lie, 2002:12).

Johnson \& Johnson menyatakan penggunaan model cooperative learning bertujuan mengoptimalkan belajar peserta didik untuk meningkatkan prestasi akademik dan pemahaman terhadap individu maupun kelompok (dalam Pathuddin, 2005:35). Model cooperative learning memiliki ciri-ciri sebagai berikut; (1) peserta didik bekerja dalam kelompok secara kooperatif, (2) kelompok dibentuk dari peserta didik yang memiliki kemampuan tinggi, sedang dan rendah, (3) bilamana mungkin, anggota kelompok berasal dari ras, budaya, suku dan jenis kelamin yang berbeda-beda, dan (4) penghargaan lebih berorientasi kelompok ketimbang individu (Ibrahim et al., 2000: 6-7). Beberapa model cooperative learning yang direkomendasikan pemerintah untuk diterapkan di sekolah yang memberlakukan Kurikulum 2013 yaitu antara lain 
discovery learning, project-based learning, problem-based learning, inquiry learning (Lampiran Permendikbud No. 103 Tahun 2014).

Sebagai contoh pembelajaran berfikir tinggi dengan menerapkan model inquiry learning Model inquiry learning adalah suatu proses untuk memperoleh dan mendapatkan informasi untuk mencari jawaban atau memecahkan masalah terhadap pertanyaan atau rumusan masalah dengan menggunakan kemampuan berfikir kritis dan logis (Direktorat Pembinaan SMA, 2014; 31). Sintaks model inquiry learning meliputi; (1) observasi/mengamati berbagai fakta-fakta sejarah, (2) mengajukan pertanyaan tentang fakta sejarah yang dihadapi, dalam tahap ini melatih peserta didik untuk mengeksplorasi melalui kegiatan menanya kepada guru atau sumbersumber lainnya, (3) mengajukan hipotesis, pada tahap ini peserta didik melakukan penalaran atau mengasosiasi, (4) mengumpulkan data terkait dengan fakta-fakta yang ditanyakan, mempredidiksi hipotesis sebagai dasar untuk merumuskan suatu kesimpulan, dan (5) merumuskan kesimpulan berdasarkan data yang dianalisis, sehingga peserta didik dapat mempresentasikan atau menyajikan hasil temuannya (Direktorat Pembinaan SMA, 2014; $31)$.

Model inquiry learning ini mampu melatih peserta didik menumbuhkan keberanian dalam mengajukan pertanyaan dan mengemukakan gagasan kepada orang lain. Penerapan model inquiry learning mendorong peserta didik terlibat secara mental maupun fisik untuk memecahkan permasalahan atau issu yang berkaitan dengan fakta sejarah yang diberikan guru. Pertanyaan/permasalahan atau issue yang ditawarkan paling tidak mengandung antara lain; (1) dua konsep atau lebih, (2) banyak alternatif, dan (3) mengundang pengambilan keputusan (Wiriaatmadja, 2002; 140-141). Ketika pembelajaran Sejarah Indonesia (wajib) kelas XI membahas KD 3.7 "menganalisis peristiwa proklamasi kemerdekaan dan maknanya bagi kehidupan sosial, budaya, ekonomi, politik, dan pendidikan bangsa Indonesia". Pertanyaan/permasalahan atau issu (Pi'i, 2016: 8) yang ditawarkan kepada kelompok diskusi antara lain sebagai berikut;

Adakah hubungan kekalahan Jepang terhadap proklamasi kemerdekaan Indonesia? Berilah penjelasan!

Siapa yang benar antara golongan pemuda atau golongan tua berkaitan dengan Peristiwa Rengasdengklok?

Siapakah yang paling berperan dalam merumuskan teks proklamasi kemerdekaan? Golongan pemuda ataukah golongan tua?

Mengapa dalam menentukan tempat pelaksanaan proklamasi kemerdekaan golongan tua lebih memilih di halaman kediaman Sukarno, sedangkan golongan pemuda lebih memilih di lapangan Ikada?

Siapakah yang berperan dalam mempersiapkan dan atau yang melaksanakan proklamasi kemerdekaan?

Dalam menyebarkan berita proklamasi, lebih penting manakah penggunaan media radio dibandingkan dengan penggunaan media lainnya?

Pertanyaan/permasalahan atau issu yang mengandung dua konsep atau lebih tersebut, dalam proses pemecahan masalah memerlukan kemampuan menalar dan berfikir logis. Selaras dengan hal tersebut, Limbach \& Waugh menyatakan bahwa untuk mengembangkan kemampuan berfikir tingkat tinggi, ada lima pembelajaran yang dapat ditempuh, yakni; (1) menentukan tujuan pembelajaran, mengajarkan melalui pertanyaan, mempraktikkan, (4) menelaah, mempertajam dan meningkatkan pemahaman, dan (5) mempraktikkan umpan balik dan menilai pembelajaran (dalam Saippudin http://wawasanedukasi.blogspot. co.id/2015/11/pengembangan-tes-untukmengukur.html). Sintaks pembelajaran yang ditawarkan Limbach \& Waugh pada prinsipnya sama dengan sintaks pembelajaran inquiry learning, keduanya mencerminkan pembelajaran yang menggunakan pendekatan saintifiks, salah satu pendekatan yang digunakan dalam Kurikulum 2013. Dalam konteks ini, pembelajaran Limbach \& Waugh pada langkah 
ke-3 "mempraktikkan" sebaiknya dalam pembelajaran sejarah ditafsirkan sebagai tahapan mengeksplorasi (mengumpulkan data yang terkait). Sedangkan kegiatan mengkomunikasikan (menyajikan) yang tidak terdapat dalam pembelajaran Limbach \& Waugh, dapat dilakukan sebagai rangkaian dari kegiatan ke-4 (menelaah, mempertajam dan meningkatkan pemahaman).

KD dan pembelajaran berfikir tingkat tinggi menuntut pelaksanaan penilaian hasil belajar dilakukan pada level yang sama, yaitu penilaian berfikir tingkat tinggi. Penilaian berfikir tingkat tinggi merupakan penilaian yang menuntut kemampuan untuk melakukan penalaran dan berfikir kritis dan logis yang mencakup dimensi proses berfikir menganalisis, mengeveluasi dan mengkreasi. Sehingga antara $\mathrm{KD}$, pembelajaran dan penilaian hasil belajar memiliki hubungan yang erat. KD menjadi acuan dalam melaksanakan penilaian hasil belajar, dan keberhasilan proses pembelajaran dalam mengantarkan pencapaian kompetensi KD diukur melalui penilaian hasil belajar.

\section{PENILAIAN HOTS}

Penilaian adalah proses pengumpulan dan pengolahan informasi untuk mengukur pencapaian hasil belajar peserta didik (Permendikbud Nomor 23 Tahun 2016) yang mencakup mencakup aspek sikap, pengetahuan dan keterampilan. Penilaian sikap merupakan bagian dari proses pembinaan peserta didik, hasil pengamatan perilaku peserta didik yang menonjol (positif dan negatif) baik di kelas maupun di luar kelas dicatat dengan menggunakan jurnal. Perilaku yang tidak menonjol diasumsikan sebagai perilaku baik dan tidak perlu dicatat. Penilaian diri dan penilaian teman sebaya sebagai penilaian penunjang yang digunakan sebagai data konfirmasi (Panduan Penilaian, 2015; 7-11). Penilaian pengetahuan digunakan untuk mengukur kemampuan pengetahuan faktual, konseptual, prosedural, dan metakognitif, serta kecakapaan berfikir tingkat rendah sampai tinggi. Penilaian pengetahuan ini menggunakan teknik tes tertulis, tes lisan, penugasan dan teknik lainnya seperti portofolio atau observasi (Panduan Penilaian, 2015; 14).

Sedangkan penilaian keterampilan untuk mengukur pencapaian kompetensi peserta didik terhadap KD pada KI-4. Penilaian keterampilan menuntut peserta didik untuk mendemonstrasikan kompetensi yang akan dicapai. Hal ini dimaksudkan untuk mengetahui capaian kompetensi yang dikuasai peserta didik yang dapat digunakan dalam menyelesaikan masalah dalam kehidupan sesungguhnya (real life). Penilaian keterampilan dapat mengunakan berbagai teknik yaitu ; (1) unjuk kerja/kinerja/praktik yaitu penilaian yang dilakukan dengan cara mengamati kegiatan peserta didik; (2) proyek yaitu kegiatan penyelidikan yang mencakup perencanaan, pelaksanaan, dan pelaporan hasil proyek dalam kurun waktu tertentu; (3) portofolio yaitu rekaman hasil hasil pembelajaraan dan penilaian yang memperkuat kemajuan dan kualitas pekerjaan peserta didik; (4) produk yaitu penilaian peserta didik membuat produk-produk, teknologi, dan seni; serta (5) teknik lainnya misalnya tertulis (Panduan Penilaian, 2015; 2223).

Dalam penelitian ini kami lebih memfokuskan pada penilaian pengetahuan berfikir tingkat tinggi. Penilaian pengetahuan bermanfaat mengukur kemampuan dimensi pengetahuan (faktual, konseptual, prosedural dan metakognitif), dan dimensi proses berfikir dari tingkat rendah sampai tinggi. Dalam kaitannya dengan dimensi proses berfikir yang diklasifikasikan menjadi 3 level kognitif, oleh Pusdiklat dilakukan sedikit perubahan dengan menggeser dimensi proses berfikir "memahami" semula berada di level berfikir tingkat menengah (Middle Order Thinkhing Skill/MOTS) yang disebut level 2 (aplikasi) diturunkan posisinya ke level berfikir tingkat rendah (Low Order Thinkhing Skill/LOTS) yang disebut Level 1 (pengetahuan dan pemahaman). Level kognitif Pusdiklat tersebut digunakan sebagai ramburambu penyusunan kisi-kisi Ujian Nasional tahun pelajaran 2015/2016 (Widana, 2016; 12).

Level 1 (pengetahuan dan pemahaman) merupakan level berfikir tingkat rendah (Low 
Order Thinkhing Skill/LOTS) yang mencakup dimensi proses berfikir mengetahui (C1) dan pemahaman (C2). Penilaian pada level 1 ini untuk mengukur pengetahuan faktual, konseptual dan prosedural. Pada dimensi proses berfikir pengetahuan (C1) menuntut kemampuan mengingat, menghapal, mendaftar, mengulang, menirukan, menyebutkan dan lain-lain. Sedangkan dimensi proses berfikir pemahaman (C2) menuntut kemampuan menjelaskan, mengklasifikasikan, membedakan, menterjemahkan, menguraikan, mengartikan, melaporkan dan lain-lain. Level 2 (aplikasi) merupakan level berfikir tingkat menengah (Middle Order Thinkhing Skill/MOTS) yang hanya mencakup dimensi proses berfikir "mengaplikasi (C3)". Penilaian pada level ini untuk menggunakan dan menerapkan pengetahuan faktual, konseptual dan prosedural. Pada dimensi proses berfikir mengaplikasi (C3) menuntut kemampuan menerapkan, menggunakan, menentukan, menghitung, dan lain-lain.

Sedangkat pada level 3 (penalaran) merupakan level berfikir tingkat tinggi (Higher Order Thinkhing Skill/HOTS). Penilaian pada level penalaran adalah penilaian yang menuntut kemampuan menalar, berfikir logis dan kreatif, serta kemampuan menginterpretasi, mencari hubungan antar konsep, dan kemampuan mentransfer konsep satu ke konsep lain. Penilaian pada level 3 (penalaran) mengukur pengetahuan metakognitif, tidak sekedar mengukur pengetahuan faktual, konseptual dan prosedural. Penilaian penalaran mencakup dimensi proses berfikir; menganalisis (C4), mengevaluasi (C5), dan mengkreasi (C6). Pada dimensi proses berpikir menganalisis (C4) menuntut kemampuan menspesifikasi aspek-aspek/elemen, menguraikan, mengorganisir, membandingkan, dan menemukan makna tersirat. Dimensi proses berpikir mengevaluasi (C5) menuntut kemampuan menyusun hipotesis, memecahkan (masalah), merefleksi, mengkritik, membuktikan, memprediksi, menilai, menguji, membenarkan atau menyalahkan. Sedangkan pada dimensi proses berpikir mengkreasi (C6) menuntut kemampuan merancang, membangun, merencanakan, memproduksi, menemukan, memperbaharui, menyempurnakan, memperkuat, memperindah, menggubah (Widana, 2016; 14).

Kemampuan yang akan dicapai pada masing-masing ranah/dimensi proses berfikir di atas sekaligus dapat pula digunakan sebagai kata kerja operasional (KKO) dalam penulisan indikator soal pada ranah yang bersangkutan. Dalam menyusun soal hots hendaknya guru tidak terjebak dalam pengelompokan KKO. Sebagai contoh kata kerja „menentukan“ pada pada dimensi proses berfikir "memahami" dan "mengaplikasi". Dalam konteks penulisan soalsoal HOTS, kata kerja „menentukan "e bisa jadi ada pada dimensi proses berfikir "mengevaluasi" apabila untuk menentukan keputusan didahului dengan proses berpikir menganalisis informasi yang disajikan pada stimulus lalu peserta didik diminta menentukan keputusan yang terbaik. Bahkan kata kerja „menentukan ${ }^{\text {ee bisa }}$ digolongkan ke dalam dimensi proses berfikir "mengkreasi", jika pertanyaan tersebut pertanyaan menuntut kemampuan menyusun strategi pemecahan masalah baru. Jadi, ranah kata kerja operasional (KKO) sangat dipengaruhi oleh proses berpikir apa yang diperlukan untuk menjawab pertanyaan yang diberikan (Widana, 2016; 5-6).

Pertanyaan-pertanyaan (soal-soal) pada penilaian berfikir tingkat tinggi (Higher Order Thinkhing Skill/HOTS) tidak selalu lebih sulit dibandingkan dengan pertanyaan pada level di bawahnya. Misalnya, pertanyaan pada level 1 (pengetahuan dan pemahaman) pada dimensi proses berfikir mengingat $(\mathrm{C} 1)$ yang menuntut kemampuan menghapal tentang istilah yang jarang digunakan atau tahun suatu peristiwa sejarah lokal yang bukan di daerahnya, hal ini tentu lebih sulit dibandingkan dengan pertanyaanpertanyaan pada level 3 (penalaran) yang menuntut kemampuan proses berfikir. Untuk menjawab pertanyaan-pertanyaan (soal-soal) pada level 3 (penalaran) peserta didik harus mampu mengingat, memahami, dan menerapkan pengetahuan faktual, konseptual, dan prosedural serta memiliki logika dan penalaran yang tinggi berkaitan dengan soal/pertanyaan itu. 
Penilaian berfikir tingkat tinggi dengan menggunakan bentuk soal yang beragam sebagaimana yang digunakan dalam PISA, hal ini bertujuan untuk mencari informasi secara detail, riel dan menyeluruh tentang kompetensi peserta didik. Adapun bentuk soal yang digunakan pada pengujian PISA yaitu; pilihan ganda, pilihan ganda kompleks (benar/salah, atau ya/tidak), isian singkat atau melengkapi, jawaban singkat atau pendek, dan uraian. Dalam penulisan soal HOTS setiap butir soal secara umum diberi dasar pertanyaan (stimulus). Dasar pertanyaan (stimulus) bentuknya bisa berupa seperti peta, bacaan, paragraf, kasus, gambar, grafik, foto, rumus, tabel, daftar kata/simbol, contoh, peta, film atau suara yang direkam. Dasar pertanyaan tersebut berfungsi sebagai pengantar untuk mempermudah memahami pokok soal (stem soal) yang menuntut pemikiran tingkat tinggi. (Adi Saputra dalam http://www. oasepembelajaran.com / 2015/09

Beberapa cara/langkah yang dapat dijadikan pedoman dalam penyusunan soal yang menuntut kemampuan berfikir tingkat tinggi (Higher Order Thinkhing Skill/HOTS) yaitu; (1) menentukan KD yang akan dibuat soal hots karena tidak semua KD menuntut berfikir tingkat tinggi, (2) menentukan perilaku yang akan diukur misalnya tentang dimensi proses berfikir menganalisis, mengevaluasi atau mengkreasi, (3) merumuskan/menyusun dasar pertanyaan (stimulus) yang menarik (mendorong peserta didik untuk membaca) dan konstektual (gambar, teks dan lain-lain sesuai dengan dunia nyata), (4) merumuskan pokok soal (stem soal) dengan singkat, jelas dan tegas yang mengukur level kognitif penalaran (menganalisis, mengevaluasi atau mengkreasi), dan (5) pilihan jawaban bersifat homogen dan berfungsi.

Berikut ini disajikan contoh-contoh soal pilihan ganda/uraian sesuai dengan dimensi proses berfikir dan level kognitif dari berfikir tingkat rendah sampai dengan level berfikir tingkat tinggi.

\begin{tabular}{|c|c|c|c|}
\hline No & $\begin{array}{l}\text { Level } \\
\text { Kognitif }\end{array}$ & $\begin{array}{ll}\text { Dimensi } & \text { Proses } \\
\text { Berpikir } & \end{array}$ & Soal Pilihan Ganda/Uraian \\
\hline 1. & \multirow[b]{2}{*}{ 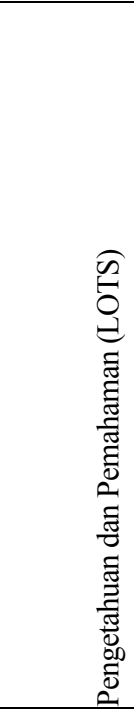 } & Mengingat & $\begin{array}{l}\text { Pada zaman perunggu (perundagian) manusia purba telah memiliki keahlian } \\
\text { di bidang metalurgi yaitu kemampuan dalam mengecor logam perunggu. } \\
\text { Zaman ini banyak meninggalkan benda-benda sejarah antara lain yaitu ... } \\
\text { kapak pendek dan moko } \\
\text { kapak persegi dan lonjong } \\
\text { keranda dan candrasa } \\
\text { moko dan kapak sepatu } \\
\text { kapak pendek dan candrasa }\end{array}$ \\
\hline 2. & & Memahami & $\begin{array}{l}\text { Selama } 32 \text { tahun masa pemerintahan orde baru telah berhasil melaksanakan } \\
\text { pemilu sebanyak enam kali. Pemilu di era pemerintahan Suharto tersebut } \\
\text { antara lain memiliki ciri yaitu .... } \\
\text { asas langsung, umum, bebas, rahasia, jujur dan adil } \\
\text { diikuti oleh berbagai macam partai-partai politik } \\
\text { adanya mobilisasi PNS untuk memenangkan golkar } \\
\text { memilih anggota DPR, presiden dan wakil presiden } \\
\text { deselenggarakan dalam waktu singkat dan menyeluruh }\end{array}$ \\
\hline 3. & 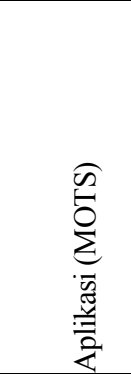 & Menerapkan & $\begin{array}{l}\text { Bila Anda seorang peneliti, dan Anda telah berhasil mengumpulkan } \\
\text { sumber-sumber sejarah, maka langkah awal yang harus Anda lakukan } \\
\text { adalah .... } \\
\text { menjaga keaslian sumber sejarah } \\
\text { memferifikasi sumber sejarah } \\
\text { menafsirkan sumber sejarah } \\
\text { menentukan topik penelitian } \\
\text { menulis sejarah/historiografi }\end{array}$ \\
\hline
\end{tabular}




\begin{tabular}{|c|c|c|c|}
\hline 4. & & Menganalisis & $\begin{array}{l}\text { Setelah terjadi kesepakatan di Rengasdengklok, Sukarno-Hatta dan } \\
\text { golongan pemuda bersama-sama menuju Jakarta untuk melakukan rapat } \\
\text { koordinasi mempersiapkan rencana pelaksanaan kemerdekaan. Sebelum } \\
\text { rapat dimulai, Sukarno dan Hatta menemui Jenderal Nishimura sebagai } \\
\text { upaya untuk menjajagi sikap Jepang. Soekarno-Hata mengajukan } \\
\text { pertanyaan "bagaimana kalau besuk pagi bangsaku melaksanakan } \\
\text { kemerdekaan?", Jenderal Nishimura menjawab "kami akan tetap } \\
\text { mempertahankan status quo". } \\
\text { Perhatikan pernyataan berikut terkait dengan bacaan di atas! } \\
\text { Jepang akan membantu proklamasi kemerdekaan Indonesia melalui Maeda } \\
\text { Jepang akan menyerahkan Indonesia kepada Belanda } \\
\text { Jepang akan mewujudkan janji kemerdekaan kepada Indonesia } \\
\text { Jepang akan menyerahkan kekuasaan atas Indonesia kepada Sekutu } \\
\text { Jepang tidak merelakan Indonesia melaksanakan proklamasi kemerdekaan } \\
\text { Jepang akan mempertahankan kekuasaannya sampai Sekutu datang. } \\
\text { Berdasarkan pernyataaan tersebut yang merupakan kesimpulan dari sikap } \\
\text { Nishimura ditunjukkan pada nomor... . } \\
\text { (1), (2), dan (3) } \\
\text { (1), (3), dan (5) } \\
\text { (2), (3), dan (4) } \\
\text { (2), (4), dan (6) } \\
\text { (4), (5), dan (6) }\end{array}$ \\
\hline 5. & & Mengevaluasi & $\begin{array}{l}\text { Pada masa demokrasi liberal (1950-1959) kondisi politik Indonesia tidak } \\
\text { stabil. Kabinet sering mengalami jatuh bangun. Selama } 9 \text { tahun terjadi } 7 \text { kali } \\
\text { pergantian pemerintahan. Konstituante gagal melaksanakan amanah Pemilu } \\
1955 \text { dan hanya dijadikan sebagai ajang perdebatan dan pertentangan antar } \\
\text { kelompok partai. Kondisi ini ditambah lagi dengan adanya gerakan } \\
\text { sparatisme munculnya Pemberontakan PRRI/Permesta. Untuk } \\
\text { menyelamatkan bangsa dan negara Presiden Sukarno pada tanggal } 5 \text { Juli } \\
1959 \text { mengeluarkan Dekrit Presiden. } \\
\text { Hal ini membuktikan bahwa demokrasi liberal .... } \\
\text { belum waktunya untuk diterapkan } \\
\text { presiden sebagai kepala pemerintahan } \\
\text { ekskutif gagal menjalankan pemerintahan } \\
\text { tidak cocok diterapkan di Indonesia } \\
\text { tidak berfungsinya partai-partai politik }\end{array}$ \\
\hline 6. & 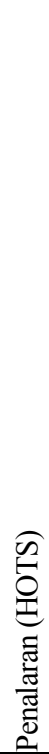 & Mengkreasi & $\begin{array}{l}\text { Kemerdekaan Indonesia yang dicapai pada tanggal } 17 \text { Agustus } 1945 \\
\text { merupakan momentum yang tepat karena di satu sisi pemerintah Jepang } \\
\text { telah menyerah kepada sekutu, sedangkan di sisi lain sekutu belum datang } \\
\text { ke Indonesia. Momentum yang tepat inilah dimanfaatkan oleh founding } \\
\text { fathers (pendiri negara) untuk memproklamasikan kemerdekaan Indonesia. } \\
\text { Peristiwa yang sangat penting bagi bangsa Indonesia tersebut terjadi setelah } \\
3 \text { hari setelah pemerintah Jepang menyerah kepada sekutu, dan merupakan } \\
\text { bangsa yang pertama di Asia-Afrika yang berhasil mencapai kemerdekan } \\
\text { pasca Perang Dunia II. } \\
\text { Petunjuk. } \\
\text { Berdasarkan deskripsi di atas buatlah karya tulis minimal } 5 \text { halaman tentang } \\
\text { makna kemerdekaan Indonesia di berbagai bidang kehidupan, dengan } \\
\text { ketentuan; kertas A4, jenis huruf times new roman ukuran 12, spasi } 1,5 \\
\text { margin letf } 3 \mathrm{~cm} \text {, top } 2,5 \mathrm{~cm}, \text { right } 2,5 \mathrm{~cm} \text { dan bottom } 2,5 \mathrm{~cm} \text {. } \\
\qquad \text { Sumber Pi’i (2016; 10) }\end{array}$ \\
\hline
\end{tabular}




\section{PENUTUP}

KD mapel Sejarah Indonesia (wajib) dan mapel Sejarah (peminatan IPS) sebagaimana yang terdapat Permendikbud Nomor 24 Tahun 2016 sebagian besar level kognitifnya berfikir tingkat tinggi (menganalisis, mengevaluasi dan mengkreasi). Dari $27 \mathrm{KD}$ pengetahuan untuk mapel Sejarah Indonesia (wajib) hanya terdapat 3 $\mathrm{KD}$ pada level berfikir tingkat rendah (level 1/pengetahuan dan pemahaman) pada dimensi proses berfikir "memahami", dan selebihnya, 24 KD pada level berfikir tingkat tinggi (level 3/penalaran). Hal ini menunjukkan bahwa meskipun mapel Sejarah Indonesia (wajib) diorientasikan untuk pembentukan sikap perilaku dan pendidikan karakter bangsa, tetapi tidak mengesampingkan sejarah sebagai ilmu. Sedangkan untuk mapel Sejarah (peminatan IPS), dari $29 \mathrm{KD}$ pengetahuan hanya terdapat 1 (satu) KD pada level berfikir tingkat rendah (level 1/pengetahuan dan pemahaman) pada dimensi proses berfikir "memahami", dan sebihnya, 28 KD selebihnya pada level berfikir tingkat tinggi (level 3/penalaran). Mapel Sejarah (peminatan IPS) ini lebih menekankan sejarah sebagai ilmu.

KD yang level kognitifnya berfikir tingkat tinggi menuntut proses pembelajarannya dilaksanakan pada level yang sama, yaitu pembelajaran tingkat tinggi. Pembelajaran tingkat tinggi merupakan pembelajaran yang menerapkan model pembelajaran tertentu yang mampu mengantarkan peserta didik mencapai kemampuan tuntutan KD yang level kognitifnya berfikir tingkat tinggi. Model pembelajaran yang lebih tepat digunakan dalam pembelajaran berfikir tingkat tinggi antara lain model cooperative learning. Model cooperative learning merupakan model pembelajaran yang memberikan ruang kepada peserta didik untuk membiasakan dan meningkatkan kemampuan menalar, berargumentasi, meningkatkan kecakapan, membangkitkan rasa ingin tahu, kemampuan menemukan (sense of inquiry) berfikir kritis, dan logis.
KD dan pembelajaran berfikir tingkat tinggi menuntut pelaksanaan penilaian hasil belajar dilakukan pada level yang sama, yaitu penilaian berfikir tingkat tinggi. Penilaian berfikir tingkat tinggi merupakan penilaian yang menuntut kemampuan untuk melakukan penalaran dan berfikir kritis dan logis yang mencakup dimensi proses berfikir menganalisis, mengeveluasi dan mengkreasi. Penilaian berfikir tingkat tinggi dikenal dengan soal HOTS (Higher Order Thinkhing Skill). Soal HOTS bentuknya beragam dan mengacu pada model pengujian PISA yaitu; pilihan ganda, pilihan ganda kompleks (benar/salah, atau ya/tidak), isian singkat atau melengkapi, jawaban singkat atau pendek, dan uraian.

\section{DAFTAR RUJUKAN}

Direktorat Pembinaan SMA, 2014. Modul Pendampingan Implementasi Kurikulum 2013 di SMA, Jakarta: Kemendikbud.

Ibrahim, et. al. 2000. Pembelajaran Kooperatif. Surabaya : UNESA-University Press

Lampiran Permendikbud Nomor 22 Tahun 2016 Tentang Standart Proses Pendidikan dasar dan Menengah.

Lampiran Permendikbud No 24 Tahun 2016 tentang Kompetensi Inti dan Kompetensi Dasar Pada Mapel Kurikulum 2013 Pada Pendidikan dasar dan Menengah.

Lie, A. 2002. Mempraktekkan Cooperative Learning di Ruang-Ruang kelas. Jakarta : Gramedia.

Panduan Penilaian Untuk Sekolah menegah Atas, Direktorat Jenderal Pendidikan Dasar Menengah, Kementerian Pendidikan dan Kebudayaan 2015.

Pathuddin. 2005. Model Cooperative Learning. Kompetitif dan Individualistik. 
Dalam Pembelajaran Matematika perspektif konstruktivis. Dalam Jurnal Sains dan edukasi Vol. 3. No 1, Maret 2005.

Permendikbud No. 103 Tahun 2014 Tentang Pembelajaran Pada Pendidikan Dasar dan Pendidikan Menengah.

Pi’i, 2016. Developing Historical Thinking Skill on History Learning Process at Senior Hight School Based on Curriculum 2013, makalah yang dipresentasikan dalam Seminar Internasional pada tanggal 8 Oktober 2016 di UM Malang.

PPPP BP SDM, 2014. Materi Pelatihan Guru Implementasi Kurikulum 2013, Tahun 2014, Mata Pelajaran Sejarah SMA/SMK, Jakarta: kemendikbud.

Safari, 2004. Penulisan Butir Soal Berdasarkan Penilaian berbasis Kompetensi, Jakarta: Pusat Penilaian Pendidikan Departemen Pendidikan Nasional.
Saipudin, 2015. Pengembangan Pengembangan Tes Untuk Mengukur Kemampuan Berfikir Tingkat Tinggi (HOT,) http://wawasanedukasi.blogspot. co.id /2015/11/ pengembangantes-untuk-mengukur.html, diunduh Selasa, 13 September 2016 jam 12.46 WIB.

Widana, I W. 2016. Modul Penulisan Soal Hots Untuk Ujian Sekolah, Jakarta: Direktorat Pembinaan SMA, Direktorat Jenderal Pendidikan Dasar dan Menengah Kementerian Pendidikan dan Kebudayaan.

Wiriaatmadja, R. (2002). Pendidikan Sejarah di Indonesia: Perspektif Lokal, Nasional dan Global, Bandung: Historia Utama Press.

Zuhdi, S. 2014. Perspektif Lokal Dalam Sejarah Nasional: Pelajaran Wajib atau Dalam Peminatan,Makalah yang dipresentasikan dalam Sarasehan Nasional pada tanggal 3 April 2014 di Surakarta, Jawa Tengah. 